\title{
Civil Society, Rights and Welfare: Exploring the Implementation of the Convention
}

\author{
on the Rights of the Child in Cambodia
}

\begin{abstract}
This study examines Cambodia's implementation of the UN Convention on the Rights of the Child (CRC). Corpus analysis of civil society organisations' submissions to the United Nations' Universal Periodic Review reveals a raft of CRC violations including sexual abuse, trafficking and child labour. This is due to political and bureaucratic failings. The wider significance of this lies in underlining how the disjuncture between state and civil society underpins ongoing violations. Future progress depends on strengthened mobilisation yet increasing repression of civil society makes this unlikely. Accordingly, the prospects are bleak with children in Cambodia continuing to suffer widespread rights violations.
\end{abstract}

Key Words: Children, Young People, Rights, Civil Society, Cambodia

Introduction

This study examines Cambodia's implementation of the United Nation's Convention on the Rights of the Child (CRC) from the perspective of civil society organisations (a 'child' here is defined as a person under eighteen years of age). The country is an appropriate locus of enquiry because it has one of the youngest populations in the world. One third of citizens are under 15 years of age and, 11 per cent of the total population is under 5 years of age (UNICEF, 2019a: 3). Moreover, it is almost three decades since the country ratified the CRC in 1992, making it an appropriate juncture to assess progress. Children's rights are crucial because, as a recent UN account notes, 'not every child gets to enjoy a full 
childhood and too many are still cut short. In Cambodia, malnutrition rates are among the highest in the region. Children are not achieving the standards of learning needed for their age groups' (UNICEF, 2019b: 1). According to a prominent international children's rights index (KidsRights Foundation and Erasmus University Rotterdam, 2021), Cambodia ranks a lowly 128 out of 181 countries. Based on a raft of indicators (including health, education and child protection), it concluded that the country's phenomenal economic development (with an annual growth rate of 8 per cent between 1998 and 2018, World Bank, 2021: 33) has not resulted in an improvement in the situation of children. The malaise is illustrated by the fact that 35 out of 1,000 children die before reaching the age of five; 1 -in-2 children have experienced severe beating; nearly 49 per cent of children are multi-dimensionally poor (i.e., they have suffered at least three types of deprivation); and 32 per cent are stunted (UNICEF, 2019: 6-7). In addition, development indicators suggest that, 'A child born in Cambodia today will be only 49 per cent as productive when grown as she could be if she enjoyed full quality education, good health, and proper nutrition during childhood' (World Bank, 2021: 28).

Despite the evident failings, systematic attention to CRC implementation in Cambodia has hitherto escaped scholarly attention. The present benchmark study aims to address this lacuna. Its overarching objective is to explore civil society organisations' views on the issues, progress and challenges on the implementation of the Convention on the Rights of the Child in Cambodia using CSOs' submissions to the Third Cycle United Nations Universal Periodic Review (UPR). It uses critical discourse analysis to examine the corpus of government and civil society organisations' reports submitted to the UPR in 2018 (and covering the preceding five years). This study focuses on CSOs' discourse because civil society participation is a foundational aspect of the UPR (throughout the term civil society organisation is used - or its abbreviation, CSO; it is synonymous with the term 'non-governmental organisation', often abbreviated to NGO). The United Nations policy guidance is explicit: 'the UPR should ensure the participation of all relevant stakeholders, including non-governmental organizations' (Office of the High Commissioner for Human Rights (OHCHR), 2011: 7). The UPR reports are a rich data source that complements official narratives, thereby providing 'situated knowledge' about the prevailing rights 
environment in the country. In turn, the analysis throws a critical light on government claims that it: 'is still committed to promoting human rights [... and] strengthen[ing] the implementation of the existing laws to be more effective... and via the implementation of necessary measures towards the promotion and protection of fundamental rights and human dignity' (Government of Cambodia, 2018: 18).

Accordingly, the study aims are to: identify what issues civil society organisations highlight when reporting on $\mathrm{CRC}$ implementation; understand the priority that they attach to them; examine the language-use associated with implementation issues ('framing'); and reflect on the contrasts and commonalities between government and civil society discourse. The remainder of the paper is structured thus: following an outline of the research context and a brief background history of Cambodia and the UPR, the study methodology is described. Attention then moves to the findings. First, with analysis of rights issues and issue-salience; followed by analysis of framing. The concluding discussion summarises the main findings and reflects upon their implications.

The main arguments in the following analysis are that there is a major disjuncture between the Cambodian Government's rhetoric on CRC implementation and the situated knowledge in civil society organisations' UPR submissions. The latter reveal widespread, ongoing child rights violations and highlight government failure to act on the recommendations of earlier rounds of the UPR. The implications of the present analysis for the future of CSOs in Cambodia, and their ability to advocate on behalf of children and children's rights are serious. Under increasingly authoritarian governing practices, (notably, with the passing of the 2015 NGO Law), it appears that CSOs will have at best limited, or more likely, no leverage and scope to push the government further on key children's rights issues identified in this study. Future progress depends on strengthened mobilisation. However, in the face of the increasing repression of civil society, this is highly unlikely. Without fundamental revisions to the power of the UN and the justiciability of the CRC and/or regime change, over coming years children and young people in Cambodia will continue to be subject to widespread rights violations. 


\section{Research Context}

This section sets out the research context by drawing on a diverse literature offering different disciplinary perspectives and methodologies to reveal the challenging social and political context facing children in today's Cambodia. The country is a constitutional monarchy, with a population of over 16 million inhabitants. Children represent just over a third (36 per cent) of the population $(5,854,000)$ (UNICEF, 2017: 3). At the outset of the 1990s Cambodia was weakened after twenty years of war, including genocide under the Khmer Rouge regime. Pol Pot, the maniacal leader of the Khmer Rouge, viewed children as integral to the revolution. He pronounced that: 'Being young, you are at the most receptive age, and capable to assimilate what the revolution stands for, better than anyone else' (Locard, 2004: 144). As Jegannathan, Kullgren and Deva (2014: 75) note, 'the spillover of the Vietnam War and the social engineering and pogrom of Pol Pot regime in the 1970s resulted in collective trauma of the entire population. A million and a half died due to starvation and sickness, half a million were eliminated in the name of agrarian revolution and about two million people were internally displaced between 1975 and 1978'.

The United Nations was pivotal to reconstruction. In the aftermath of the conflict, it organised elections and paved the way for international non-governmental organisations and agencies to commence development projects to promote human rights and democracy, notably with an emphasis on children. Also, in the wake of the conflict, the country ratified the United Nation's Convention on the Rights of the Child. Following reconstruction, Cambodia has transformed into one of the fastestgrowing economies in the world. According to official data, the poverty rate also seen a dramatic decline from 47.8 per cent in 2007 to 12.9 per cent today. Notably, there is a sharp urban-rural divide with approximately 90 per cent of the poor living in the countryside (World Bank, 2021).

Recent years have also seen key policy developments such as the National Action Plan on Early Childhood Care and Development 2014-2018 (Kingdom of Cambodia, 2014), and Positive Parenting Strategy 2017-2021 (Kingdom of Cambodia, 2017). Pressure to safeguard younger generations has also 
come from the Asian Development and World Banks. The latter's agenda aligns with the rise of neoliberalism in the country and the privatisation and deregulation of services. Its influence can be seen in school education with the introduction of standardised testing and an emphasis on broad competencies in a narrow curriculum. According to critics, it is a tendency that overlooks, 'the importance of taking into consideration the cultural context to understand how it impacts upon the effective implementation of pedagogic initiatives [... and] it raises pertinent issues relating to competing cultural worldviews that are important for policy-makers to consider at both national and international levels' (King, 2020: 375).

In terms of politics and civil liberties, the situation in today's Cambodia is a troubling one that reflects authoritarian governing practices elsewhere in Asia and beyond . According to one Democracy Index the country is ranked a lowly 130 out of 167 (EIU, 2020: 12). As Hughes' (2009) account explains, the UN, the World Bank and major donor countries have accommodated a "neoliberal" doctrine of global governance at considerable cost to the national sovereignty of countries like Cambodia. The comparative success of the Cambodian People's Party (CPP), in power since the 1980s, is to a significant degree due to the Party's politico-military network making all the correct rhetorical responses to the international community, and then building the state to ensure its own dominance. In turn, the state's legitimacy deficit leads to greater dependence upon those who clearly control the power and the money, namely the donor community.

The potential benefits of civil society and government co-working on CRC implementation have a basis in social theory on knowledge exchange and governance. Notably, complementarity theory emphasizes language and how politicians attempt to cope with complexity by using civil society in policy implementation; this not only strengthens 'input legitimacy', but also promotes policy efficacy through the pursuit of shared goals (Klijn and Skelcher, 2008). However, since 2015 such hopes have faded as Cambodia has moved further towards autocracy. Before proceeding, at this point we need to acknowledge that naive de Toquevilism is unhelpful in understanding the present situation facing civil society. It is true that many CSOs are independent and seek to hold government to account, but others 
are co-opted, politicized, exclusionary, and serve vested interests (Ojendal and Ou, 2015). Against this backdrop, as Curley's (2018) cogent analysis notes, recent years have seen government introduce repressive measures, such as the 2015 Law on Associations and Non-governmental Organisations in Cambodia (the "NGO Law", alternatively "LANGO"). As she observes, 'the law 'intersects with, and consolidates, the recent trend of the government's use of legislation as a political tool to control and manipulate political opponents and government critics' (Curley, 2018: 261).

Cambodian leaders have thus confounded the efforts of the international community to promote rule of law by introducing legal reforms and overseeing an increase in the use of legal proceedings, including defamation lawsuits, against opposition politicians and members of civil society in furtherance of a patronage based political order (McCarthy and Un, 2017). As Loughlin (2021: 840) notes, since 2012, 'China's economic assistance, diplomatic backing and military exchanges have... prove[n] vital to the CPP during a transition from competitive to hegemonic authoritarianism'.

The United Nations described the immediate impact of the 2015 NGO Law, noting that, 'in 2016, civil society demonstrations calling for the release of staff members of the Cambodian Human Rights and Development Association... were forcibly dispersed... Increased police presence, including undercover police, before and during public NGO activities or events is reported' (United Nations Country Team, Cambodia, 2018: 5, para 23). Subsequent, developments highlight the regime's increasing preoccupation with self-preservation (and patrimonialism) which has ultimately come via hollowing out the rule of law and democratic electoral process established by the UN in the early 1990s. Thus, in June 2017, the 'direction of travel' for Cambodian governance became more apparent when the main opposition party, Cambodia National Rescue Party (CNRP), won almost half the popular vote. In response, the ruling Cambodian People's Party (CPP) ordered the arrest of opposition leader Kem Sokha, and the Supreme Court ordered the dissolution of the CNRP. Subsequently, the CPP won all seats in the National Assembly elections of 2019 (see Un, 2019). As a result, Cambodia has become a de facto one-party state. 
In its wake recent analysis has described the ongoing suppression of civil society:

Harassment, threats, and intimidation of civil society actors have contributed to the reemergence of a climate of fear, inducing extensive self-censorship amongst activists. Several activists have left Cambodia and resettled abroad... Rallies in Phnom Penh have not been allowed for years, even on Human Rights Day, which is a public holiday (BTI, 2021).

Furthermore, Curley, Dressel and McCarthy, (2018: 200) refer to an ongoing malaise of increasingly poor governance, political capture of the judiciary and 'the reality of state-sanctioned corruption and rent seeking, facilitated by international foreign investment, domestic contracts and bribes and kickbacks to local/regional elites, to maintain regime loyalties'. Such is the recent history of Hun Sen's methods to stay in power. As Peou (2019: 42) summarises, it relies on three factors: coercion, cooption, and control. With Chinese backing and an increasingly repressive state apparatus this means that human rights in general are viewed by the regime as deserving of lip-service to try and appease the international community, but as the concluding section of this article argues, this is legitimation in action and reflective of a general disregard of the country's international treaty obligations.

\section{A brief background and history of the CRC and its implementation in Cambodia}

(i). The First Cycle UPR in 2009

In its National Report to the first cycle UPR in 2009, the Government of Cambodia highlighted two issues relating to children's rights. The language was vague. It did not quantify the scale of government interventions and neither did it consider their impact. For example, the government noted, 'Efforts have been made in reducing the proportion of child labour for dangerous jobs through the carrying out of various projects and programs. In addition, a five-year Plan from 2006-2012 on the elimination of the severest form of child labour, have been partly implemented and other regulations pertaining to child labour and labour related issues are being drafted' (HRC, 2009, para 37); and 'Social security... In 
short, during the third legislature, the Royal Government succeeded in rescuing, and providing support to a large number of vagrants, vulnerable people including women and children... Appropriate measures have been taken to mitigate the influx and misery of homeless into urban centres' (HRC, 2009, para 50). For the first cycle UPR, the UN Country Team reported that, 'Of particular concern are... persistently high child mortality rates, the low levels of secondary education of girls ... [and] higher rates of girl child labour [compared to boys]' (UNCT, 2009: 22). Amongst the UN recommendations from the first cycle UPR to the Cambodian Government were, 'intensify its fight to eliminate forced labour and the severest forms of child labour', 'deepen actions in fighting against child prostitution and trafficking of minors', and 'continue the development of specific legislation to promote and protect the rights of the child, including civil society participation' (UN, 2010). Notwithstanding the newness of the procedure, there was strong civil society engagement with the first UPR. There were twenty-two CSO submissions, six of these were joint submissions from multiple CSOs. These gave graphic details of a range of CRC violations, including: 'There is also an explosion of videos parlors showing violence pornography. The impact of these videos are evident in both the rape of young girls below 10 years old and the rising number of cases of young children indulging in sexual violence' (People Health Development Association, 2009: 3, para 14); and, 'Families with intellectually disabled children are often overlooked... They have vain hopes for health improvement, schooling and employment; and they are frequently condemned to even greater poverty' (FI and FSMI, 2009: 3).

\section{(ii). The Second Cycle UPR in 2014}

In its National Report to the second cycle UPR in 2014, the Government of Cambodia highlighted a limited number of issues relating to children's rights. Again, the language was vague and did not quantify the scale of government interventions nor their impact. For example, 'The Education Strategic Plan 2009-2013... ensures that the children at the age of six can have access to primary schools'; and 'the Royal Government issued a sub-decree no. 162 on 25 September 2009 to establish a national 
committee whose role is to combat human trafficking, labor exploitation, and sex trade on children and women' (HRC, 2014: 22). As awareness of the process had increased in the five years since the previous review, there was a significant increase in the participation of CSOs in the second cycle UPR. There were 43 CSO submissions, 17 of these were joint submissions from multiple CSOs. These gave graphic details of a broad range of CRC violations. For example, one complained that there had been no change in the legality of corporal punishment of children since the previous UPR (Global Initiative, 2014: 8). On the administration of justice and the rule of law, CSOs complained that there was still no independent mechanism to receive and address complaints from children concerning rights violations. The discourse referred to estimates that up to 50 per cent of children charged with a felony had been treated as adults and that children face the risk of violence at each stage of the legal process (NGO Coalition on the Rights of the Child, 2014: 5). Others were concerned that the Khmer Krom (a distinct ethnic grouping) have limited access to education and to learning their mother tongue, noting that the majority of families 'are unable to afford their children's basic education, because they possess no required documents such as birth certificates, identity cards etc. There should be language schools to assist the growing number of Khmer Krom' (e.g., KKKHRDA, 2019: 2). The recommendations stemming from the Second Cycle UPR often reflected the lack of progress in children's rights since the previous cycle. For example, 'Continue government efforts to eradicate the worst forms of child labour and to improve safety standards at work' (118.70), 'Improve... efforts on child protection systems, particularly children belonging to marginalized and disadvantaged groups' (118.74); and 'Continue to pay attention to the right to health of the child' (118.155) (HRC, 2014b: 12-34).

\section{Methodology}

The present study uses critical discourse analysis to examine the UPR submissions. This 'is a type of discourse analytical research that primarily studies the way social-power-abuse, dominance, and inequality are enacted, reproduced, and resisted by text and talk in the social and political context' (Van 
Dijk, 2001: 352). There were two components, issue-salience and framing; each are now considered in turn. 'Issue-salience' is a mode of content analysis (Neuendorf, 2016). It measures the frequency of key words, ideas or meanings in policy documents. This gives an index of the relative level of attention to (and thus indicator of prioritization of) key topics amongst competing issues and agendas. This was operationalised by using a technique borrowed from electoral studies. It sub-divides the UPR reports into 'quasi-sentences' (or, 'an argument which is the verbal expression of one political idea or issue,' Volkens, 2001: 96). Dividing sentences in this way controlled for long sentences that contained multiple policy ideas and, as noted, produced a relational index of issue prioritisation. Here is a worked example - the sentence: 'In the Second Cycle UPR it was recommended that the Government of Cambodia increase investment to tackle child trafficking, yet the past five years have not seen an increase in funding" - this would be recorded as two quasi-sentences - one associated with Article 34 violations (Sexual abuse, including trafficking) and one on Article 45 violations (Failure to respond to earlier UPR recommendations). To do this deductive coding was applied to electronic copies of UPR submissions with the number of references to each issue or topic ('quasi-sentences') recorded in a database.

As noted, the second aspect of the discourse analysis centred on framing. This derives from the classic work of Goffman (1974). It refers to the way that language is expressed. It is concerned with the inherent meanings, messages and criticality in relation to policy ideas (Druckman, 2001; Heine and Narrog, 2015). As the following reveals, framing deepens the analysis for it moves beyond the level of attention to different rights issues to consider how policy actors seek to persuade others about the need for reform.

[Temporary Note - Figure 1 - about here] 
As noted, the principal data source is the third cycle (2019) UN Universal Periodic Review. It has two components: CSOs' UPR submissions and the Cambodian Government's UPR submission. These are described in detail below. First, it is germane to consider the role and significance of civil society in the UPR and how CSOs work with the review process. The UPR was established following a 2006 UN General Assembly resolution (60/251). According to its proponents, it is not designed to be an elite process. Instead, it provides the chance for each state to set out the actions that they have taken to advance human rights. Crucially, it allows civil society organisations to provide formal written submissions. Since its introduction, Cambodian civil society has embraced the UN Review process with dozens of CSOs submitting their reports. The CSO submissions constitute a rich and singular dataset that informs understanding of the role of civil society as a political space for resisting child oppression and promoting rights. Sampling is not used here. Instead, this study is an example of corpus analysis (Biber, Connor, and Upton 2007). In other words, it examines the entire, complete set of CSO submissions to the third cycle UPR. The UPR documents were all in the public domain and downloaded from the UN website. The dataset comprised thirty CSO reports submitted to the UPR in 2018. The foregoing figure under-reports the level of civil society input, for many of the UPR reports are joint submissions co-authored by several CSOs (See Appendix below for a full listing). The mean word length for the reports is 4,180 (including Appendices). Typically, the joint UPR submissions were longer. Some were over 11,000 words. There are limited requirements regarding the format or specification of the CSO submissions (Figure 1). To a significant degree, they constitute 'free text'. This preserves CSOs' autonomy and criticality. In addition, the Cambodian Government's National Report (GoC, 2019) was also analysed. It is a single document of 12,000 words in length and reports on the implementation of the Country's treaty obligations, including actions in relation to the previous UPR recommendations. Having outlined the study methodology, attention now turns to the study findings. The following discussion ranks the main child rights violations in CSOs' third cycle UPR discourse, starting with the pathology receiving the greatest issue-salience or amount of attention in the corpus (Table 1 ). 
[Temporary Note - Table 1 - about here]

\title{
Civil Society and government discourse on CRC implementation
}

\author{
(i). Sexual abuse (including trafficking and prostitution).
}

Article 34 violations ('States Parties undertake to protect the child from all forms of sexual exploitation and sexual abuse') were the first-ranked issue in CSOs' Third Cycle UPR submissions. The UPR data reveal the manifold causes of Article 34 violations. One is the rise of tourism and with it, sex tourism (Chon, Bauer and Mckercher, 2003). The explanation is cheap air travel and internet pornography. One CSO called for more data and research on the issue. It observed, 'Online child exploitation in Cambodia is a growing concern, but there is to date no dedicated research and few resources on the issue, making it harder to combat... online child sexual exploitation (OCSE) is often associated with the sexual exploitation of children in travel and tourism. Cases of child sex exploitation by foreigners show that offenders were often also convicted for producing and distributing child sexual exploitation material' (APLE Cambodia \& ECPAT International, 2018: 11).

Another cause is the cultural norm of female chastity set out in chbab srey - or 'women's law'; meaning that girls that have been exploited, raped and/or abused, frequently will not disclose it. As Hoefinger (2013: 90) notes, 'it still remains highly unreported even with the increase in available technology... familial [and other modes of] sexual abuse is one of the "hidden" aspects of Cambodian society that is extremely difficult to discuss with any degree of candour... This has to do with the traditionally required respect of elders from youngsters and concerns over public familial shame... and disrespecting rigid kinship hierarchies and roles'.

Several CSOs gave explanations for these types of violation. For example, 'The demand for virgin girls in Cambodia is a big business that thrives due to cultural myths' (ECPAT International, 2018: 
5). One of these is that sleeping with a virgin will cure HIV, another is that it will increase male virility (Haworth, 2014).

A third cause of the prevalence of sexual abuse violations is the failure of earlier policy interventions. For example, Page et al (2015: e010854) note that reforms aimed at, 'suppressing human trafficking and sexual exploitation amplified risks not only of sex workers contracting HIV but being subject to abuse'. They continue, 'brothels (previously acknowledged and engaged in HIV prevention programming) were closed and police crackdowns prompted an exodus of brothel-based female sex workers to entertainment venues and street-based sex work'. For its part, the GoC (2018, para 43) asserted that it, 'has strongly made efforts to combat trafficking in persons, especially women and children'. However, the scale of activities reported by government are manifestly unequal to the scale of the problem. For example, it reports that nation-wide, just 45 arrest warrants were issued against suspected traffickers in 2017 (GoC, 2018, para 44).

Another cause is the trafficking of children for sexual purposes. The explanation is sex tourism, and increased demand for child prostitutes, as well forced marriage. Core strands in the civil society discourse were concerned with the dearth of official data on the issue, and the need for greater use of undercover investigative techniques by the authorities (CRC-Cambodia and ADIC, 2017: para 31). Further attention centred on the criminalisation of victims trafficking. For example, one noted that 'Anti-trafficking efforts should focus on the people engaged in exploitation of women and children, not on those who are exploited in the sex industry' (Cambodian NGO Committee on CEDAW, ActionAid Cambodia et al. 2018: 7).

The cause of the rise of online child sexual exploitation is axiomatic - the rapid global increase digital technologies. The explanation is criminals seeking profit from child abuse. One CSO's complaint typified the wider view that, 'Online child exploitation in Cambodia is a growing concern, but there is to date no dedicated research and few resources on the issue, making it harder to combat. [... It $]$ is 
often associated with the sexual exploitation of children in travel and tourism' (APLE Cambodia \& ECPAT International, 2017: 12).

Yet another cause of child sexual abuse is endemic official corruption (in part, fuelled by low pay for police and government officials). Again, the explanation is an economic one, combined with criminality and self-gain. As one CSO submission explained: 'Young girls frequently become victims of rape and torture during their employment in brothels, beer gardens and massage parlours. It has been revealed that public authorities are often unable to target major offenders and kingpins due to their alleged ties to certain government officials' (International Trade Union Confederation, 2018: 11).

(ii). Education

Over the past decade there has been a raft of policy initiatives leading to advances in education such as the Master Plan for Child Friendly School 2015-2018 (RGC, 2015), the Education Strategic Plan 20142018 (RGC, 2014), Policy on Child Protection in School 2016, and the National Policy on Early Childhood Care and Development in 2010 and Action Plan 2014-2018 (Kingdom of Cambodia, 2014, 2016). These have mainly occurred at primary level. Notably, in 2016/17, official data showed that 93 per cent of children were enrolled in primary schools. In contrast, the gross enrolment rate in lower secondary education was just 59.1 per cent (circa 2017-18). When the dropout rate is considered (17.5 per cent in 2016-17), it means under a half of children are receiving lower secondary education (UNICEF 2019: 7). As Kelshall et al (2019: 86) observe, Cambodia has made great strides in expanding access to primary education. [Yet] Much less progress has been made with respect to quality... delivering on quality will be an uphill struggle'.

Notwithstanding these gains, Article 28 violations ('States Parties recognize the right of the child to education, and with a view to achieving this right progressively and on the basis of equal opportunity') receive widespread attention in the UPR discourse. Notably, the government itself 
recognises the need for further reforms: 'some challenges remain... the continuation of education at high school level has not been completed and this causes a difficulty and limitation in skill selection and the promotion of quality at the higher education' (GoC, 2018: para 67). Crucially, the UPR data also show how access to education is riven with inequalities. For example, 'the overall participation in early childhood education by children 3-5 years old is still low - especially for children in remote areas, ethnic minority children, children with disability, and children from poor families... The lack of age-appropriate reading and play materials for young children - especially children under the age of six - poses a great challenge in improving learning and emergent literacy for children' (CRC-Cambodia and ADIC, 2017: 14).

(iii). Legal protection issues

The CRC says that 'States Parties shall take all appropriate legislative, administrative, social and educational measures to protect the child from all forms of physical or mental violence, injury or abuse, neglect or negligent treatment'. This is reinforced by the UN Standard Minimum Rules for the Administration of Juvenile Justice ("The Beijing Rules") (OHCHR, 1985). Notwithstanding this, Article 19 violations received widespread condemnation in the civil society discourse. In contrast, the government's UPR submission gives scant attention to the issue, only offering the generalised statement, 'The Kingdom of Cambodia has laws that guarantee the protection of children from degrading treatments, forced labour, sexual exploitation and sexual abuse' (GoC 2018, para 27), followed by a descriptive list of enactments with little discussion of their efficacy.

In contrast, and notwithstanding earlier UN Development Programme initiatives on access to justice in the early 2000s (Popovic, Melim-McLeod and UNDP, 2009) CSOs' UPR submissions show that access to justice remains a key issue. They highlight the fact that there is no separate juvenile system for children involved in criminal proceedings, legal aid for children is inadequate and that there is a lack of child-specific knowledge and skills of officials involved in children's cases, including police, 
prosecutors, judges and lawyers. As Joamets and Ngouv (2019: 142) note, in practice there are many infringements. Not all children get access to legal representation, they are not treated respectfully and in a child-friendly manner in the hearings, "common are "informal" payments to meet a child and extra fees for certain inquiries or to speed up the trial, instead of educating the children who are punished'. Thus, one CSO called on the authorities to do more to, 'provide information on the legislation process and specific law applicable to protect children in different settings in consultation with civil society organizations and development partners within the development process, with a sufficient budget allocation for implementation in all relevant ministries' (Child Rights Coalition Cambodia, 2018: 6). Whilst another demanded 'Strengthen[ed] coordination and cooperation between the various government ministries, departments and agencies... Specifically coordination between law enforcement, judiciary and social services' (APLE Cambodia and ECPAT International, 2017: 9).

\section{(iv). Child labour}

Almost one-in-five (19 percent) of Cambodian children aged 5 to 17 are economically active (UNCT, 2018: 11, para 58). Violation of CRC provisions on child labour are commonplace and receive repeated attention in the civil society discourse. Article 32 asserts that, 'States Parties recognize the right of the child to be protected from economic exploitation and from performing any work that is likely to be hazardous or to interfere with the child's education, or to be harmful to the child's health or physical, mental, spiritual, moral or social development [... and] provide for a minimum age or minimum ages for admission to employment'. Related protections also stem from the International Covenant on Civil and Political Rights (United Nations, 1966). Yet international treaty obligations and Cambodia's domestic legal code are fraught with contradictions. For example, whilst the CRC proscribes child labour, the domestic legal code says "light work" activities are lawful for child labour as young as 12 years old (National Assembly of Cambodia, 1997). In 2018 government issued a Royal Decree authorizing the National Committee on Child Labor (NCCL) to commence work. Yet the UPR data reveal it constitutes 
an inadequate, under-resourced official response. The government's UPR submission does not even acknowledge ongoing Article 32 violations. Instead, it asserts that 'the Labour Law prohibits the use of children in heavy labour' (GoC, 2018: 7, emphasis added) and it reports troublingly low numbers of child labour cases coming before the courts: 34 cases in 2014, 16 in 2016, and only 2 cases in 2017.

In contrast, CSOs' UPR discourse offers coruscating criticism. It notes that the NCCL employs just one child labour inspector in each province, a total of 25 for the whole country. As one CSO submission puts it: 'The abuse of the rights of children in Cambodia remains a major problem. Statistical surveys carried out by the government demonstrate that there are at least 755,245 economically active children in Cambodia [... and] 55.1 per cent of these are engaged in hazardous labour, including child prostitution' (International Trade Union Confederation, 2018: 8). Notwithstanding the fact that, as Arnold and Hess (2017: 2198) observe, Cambodia is promoted as an "ethical" garment manufacturing enclave, 'state-society relations are characterized by violent neoliberalism and an authoritarian, neopatrimonial state'. As a burgeoning body of work highlights, challenges abound; including under-age workers, forced overtime, dangerous working conditions and, a lack of maternity leave and childcare facilities (Hall, 2000; Chiu, 2007; Shea et al, 2010). Such issues extend across employment sectors. A core trope in the UPR data is the high incidence of children as domestic workers. The International Labor Organisation notes that their exclusion from Cambodian labour laws is having a devastating effect. Primarily, this affects girls between the ages of 7 and 17 working as domestic servants in third party homes where they are exposed to often hazardous, unregulated work (International Labor Organisation and International Trade Union Confederation, 2018: 5).

\section{(v) Health}

Article 24 of the CRC asserts, 'States Parties recognize the right of the child to the enjoyment of the highest attainable standard of health and to facilities for the treatment of illness and rehabilitation of health'. Weighed against this obligation, Cambodia has made significant progress in some areas of 
healthcare, such as maternal and infant mortality (decreased from 66 per 1,000 live births in 2005 to 28 per 1,000 in 2014, World Bank, 2020). In its UPR Report the Government said it was 'prioritizing... rural and remote areas and marginalized and vulnerable groups, especially women, children and elders in order to improve people's daily health situation and welfare' (GoC, 2018, para 84).

However, CSOs' UPR discourse offers a contrasting picture and points to a raft of Article 24 violations, including malnutrition. Recent analysis shows one-in-three Cambodian children under 5 years of age are stunted such that, 'targeted and integrated cross-sectoral policies that reinforce comprehensive early childhood interventions are needed for improving nutritional status as part of a wider set of child poverty reduction measures in Cambodia' (Karpati, et al, 2020: 134). This is reflected in the UPR discourse. One CSO complained: 'the level of children under 5 suffering from malnutrition has remained high with 32 per cent of these children showing sign of stunting, 24 per cent being underweight and 10 per cent being wasted... Malnutrition also reveals an equity gap in Cambodia with stunting being more common in rural areas... and is least common among the children of more educated mothers and wealthier families' (CRC-Cambodia and ADIC, 2017: 14).

As noted, Cambodia has the youngest population in Southeast Asia. The sexual and reproductive health issues facing young people was a further core strand of CSOs' UPR discourse. Several submissions noted the link to poverty and the need for government to do more in education and awareness programmes. For example: '37 percent of teenagers who have never been to school have begun childbearing... there is a need to specifically address reproductive health issues of adolescents and youths, particularly those in rural areas. There is almost universal knowledge of modern methods of family planning, but unmet needs continue to be high, indicating gaps in access to services (Social Action for Community and Development; Rainbow Community Kampuchea et al, 2017: 14). 
The CRC states asserts that, 'No child shall be deprived of his or her liberty unlawfully or arbitrarily. The arrest, detention or imprisonment of a child shall be in conformity with the law... every child deprived of liberty shall be treated with humanity... and in a manner which takes into account the needs of persons of his or her age' (Article 37). According to the government's UPR submission, 'Prisons have been... respecting the human rights principles... and the policy of the RGC [Royal Government of Cambodia] on the protection and promotion of women's and children's rights' (GoC 2017: para 42). In contrast, the CSO submissions were often damning in their criticism. For example one noted that: 'The justice system in Cambodia is not yet fully equipped to respond to the needs of children who conflict with the law - whether as victims, witnesses or suspects. Necessary procedures and facilities for dealing with minors in the criminal justice system are lacking... Additionally, there is still no independent mechanism to receive and address complaints from children concerning violations of their rights' (CRCCambodia and ADIC, 2017: 15).

Failings in child detention and custody are a prominent theme. One CSO observed that: 'of concern is the increase of pregnant women in prison and children living with their mothers in prison. The Prison Law of Cambodia allows mothers of children under age 3 to live with their child in prison. Article 41 of the Prison Law... requires these children's care to be paid for by the State; yet, in reality, the government only allots 35 cents per day per child, and the mothers are forced to pay themselves' (Cambodian NGO Committee on CEDAW, ActionAid Cambodia et al. 2018: 9).

(vii) Violence (including corporal punishment)

Article 19 of the CRC requires that, 'States Parties shall take all appropriate legislative, administrative, social and educational measures to protect the child from all forms of physical or mental violence, injury or abuse'. However, violence is a major theme in the civil society UPR discourse. For its part the government's UPR submission makes limited and generalised reference to the issue, such as upholding 'respect of rights and human dignity, respect of freedom principle, democracy and social justice, non- 
violence, drug abuse and all forms of discrimination' (GoC, 2018: para 82). Yet, recent analysis reveals the widespread nature of the problem: 'the occurrence of violence was commonly witnessed in their homes, schools, and communities. Approximately 60 per cent of males and females reported experiencing emotional, physical, or sexual violence during childhood' (UNICEF, 2020: 7). Extant work underlines the diverse causes of this violence, including the country's recent history of conflict (Glenn and Thomas, 1992); and how the incidence of violence varies with parents'/ guardians' age, education and household economic status. Troublingly, prevailing social attitudes compound the problem. A recent study found that a significant proportion of women supported beating sons (69.2 per cent) and daughters (67.2 per cent) (Dalal et al, 2018).

The principal strand of CSOs' UPR discourse on violence against children highlighted inconsistencies and shortcomings in the domestic legal code. Article 1045 states that 'the parental power holder may personally discipline the child to the extent necessary'. Article 1079 extends the 'right to discipline' to the child's guardian (National Assembly of Cambodia, 2004). Thus, for example, one CSO complained that: 'In Cambodia, corporal punishment of children is still lawful... Although the Action Plan to Prevent and Respond to Violence Against Children 2017-2021 clearly committed the Government to prohibiting all corporal punishment in legislation by the end of 2019 [Kingdom of Cambodia, 2017], no progress has so far been made' (Global Initiative to End All Corporal Punishment of Children, 2018: 4).

\section{(viii) Nationality}

Article 7 of the CRC states that: 'The child shall be registered immediately after birth and shall have the right from birth to a name, [and] the right to acquire a nationality... States Parties shall ensure the implementation of these rights in accordance with their national law and their obligations under the relevant international instruments in this field, in particular where the child would otherwise be stateless'. The government's UPR submission offers a complacent view, noting that: 'In the Kingdom of 
Cambodia, childbirth registration and gaining of Khmer nationality have legal norms defining clear procedures that have been implemented without any discrimination' (GoC, 2017: 8). In contrast, the present analysis shows that Article 7 nationality violations are commonplace. The principal tropes centred on the issue of statelessness, particularly, for children of foreign parents born in Cambodia, and how the absence of a birth certificate denies children access to social welfare. This is captured in the following example: 'Without birth certificates, children are excluded from accessing the education system... only 9 per cent of ethnic Vietnamese go to state schools. Similarly, members of this community who lack birth certificates are barred from accessing healthcare and other social services (Minority Rights Organisation (MIRO), Khmer Kampuchea Krom for Human Rights and Development Association, et al, 2017: 11).

\section{(ix). Child marriage}

Child marriage is defined as: 'a marriage in which at least one of the parties is a child. It also refers to the act of marrying off children, usually young girls, with or without their consent. Some forms of child marriage are related to commercial sexual exploitation of children, in cases where child marriage is linked to forced child labour, slavery and bondage, servitude or payment of a dowry' (Interagency Working Group, 2016: 3). It is proscribed under Article 16(2) of the Universal Declaration of Human Rights (UDHR) ('Marriage shall be entered into only with the free and full consent of the intending spouses') (United Nations, 1948). In Cambodia the legal minimum age of marriage is 18 years, or 16 years with parental consent. Viewed in historical context, child marriage was a scourge during the Cambodian genocide, 1975-1979 (Tyner, 2018); yet it continues today. Cambodia Demographic and Health Survey data show a high prevalence of under-age marriages in rural or remote geographic locations. For example, they make up 36 per cent of all marriages in Mondulkiri and Ratanakiri provinces (Chan and Ream, 2017: 1). Despite the scale of the problem, it is not mentioned in the government's UPR submission. In contrast, the CSO discourse underlines its diverse and negative impacts, as typified 
by the following troubling assessment, 'Child marriage has a multifaceted and profound impact on children's lives, affecting their health, education, psychological development, social life, relationships and increased risk to future adversities... Child brides often drop out of school and become pregnant, and these early pregnancies have a greater risk of ending in maternal or infant death' (CRC-Cambodia and ADIC, 2017: 6).

\section{(x). Failure to respond to earlier UPR recommendations}

Article 45 of the CRC requires the 'effective implementation of the Convention'. However, a repeated aspect of the Third Cycle discourse was CSOs' anger and frustration at government's failure to address UN recommendations from earlier UPR cycles. For example, one noted that 'in the country's last UPR in 2014, [... it was] recommended to the Government of Cambodia to strengthen the protection of the rights of the child through the implementation of the new draft of the national plan to eliminate the worst forms of child labour for the period 2013-2018... No information can be found about the drafting of a new national plan of action' (APLE Cambodia and ECPAT International, 2017: 12). The civil society discourse on the government's failure to address earlier UPR recommendations covers most CRC articles. For example, one CSO complained that 'Some recommendations are partially implemented, and some are still not yet implemented and require additional efforts to follow up the progress during the upcoming 3rd UPR Cycle of Cambodia'. Special concerns included the failure of the government to address recommendation on adequate resourcing of children's welfare and the limited number of trained social workers (with one social worker covering 12 districts) (Child Rights Coalition Cambodia, 2018: 6). The causes and implications of the Cambodian Government's failure to address previous UPR recommendations are given further consideration in the discussion and conclusion (see below).

(xi). Residential care institutions and facilities 
Article 9 of the CRC says that 'States Parties shall ensure that a child shall not be separated from his or her parents against their will, except when competent authorities subject to judicial review determine, in accordance with applicable law and procedures, that such separation is necessary for the best interests of the child'. Yet approximately three-in-four children living in residential care institutions have at least one parent who is known to be alive (UNICEF, 2019a: 3). Accordingly, Article 9 violations are repeatedly highlighted in the UPR data. As work by Stark, et al (2017: 1866) reveals, 'Nearly 1 of every 100 children in Cambodia is living in residential care. This raises substantial concerns for child health, protection and national development'. Official data reveal that there are 639 Residential Care Institutions and Facilities (RCIFs) with the combined total of 26,187 child residents (Ministry of Social Affairs, Veterans and Youth Rehabilitation, 2017: 34). Recent policy developments designed to address the issue include a government Action Plan for Improving Child Care that has a target of safely returning 30 per cent of children in residential care. Yet the government's UPR report shows that just 56 childcare centres have been closed with 549 children reintegrated into families and communities (GoC, 2017: para 31). CSOs' UPR discourse highlights the lack of resources to address Article 9 violations. For example, one complained that, 'Cambodia's child protection and welfare services remain weak, understaffed and lack funds' (APLE Cambodia and ECPAT International, 2017: 6). Another demanded that the government 'Increase [the] budget... so children living in Residential Care Institution and Facilities ... receive better education, nutrition and less violence' (CRC-Cambodia and ADIC, 2017: 15).

\section{(xii). Children with disabilities}

Article 23 of the CRC requires that, 'States Parties recognize that a mentally or physically disabled child should enjoy a full and decent life, in conditions which ensure dignity, promote self-reliance and facilitate the child's active participation in the community'. Yet a burgeoning literature underlines the exclusion and marginalisation of disabled children in Cambodia (e.g., Gartrell, 2010; Mak and Nordtveit, 2011). The CSO discourse mirrors this and underlines a history of exclusion from schooling (e.g., 
'Children with disability were either never enrolled in school or dropped out' (Child Rights Coalition Cambodia, 2018, 4), or that the educational needs of students with disabilities are typically not addressed by textbooks and learning materials in Cambodia. Most classroom activities are not adapted to incorporate the needs of various types of disabilities (e.g., recognizing the need to engage students who are blind or deaf in the classroom)'. Other alluded to the institutionalisation of disabled children: 'The existing programs for assisting street children are underfunded, thus State-run Residential Care Institutions and Facilities for street children and children with HIV and disabilities are poorly maintained' (CRC-Cambodia and ADIC, 2018: 8). For its part, the Cambodian Government's UPR report cites the National Strategic Plan on Disability (2014-2018). Its goals include improving the living conditions of persons with disabilities and their families and 'respecting their dignity from the birth and independent living with full welfare; and promoting equality of women, children, and all kinds of persons with disabilities' (RGC, 2018:14). Whilst these goals might be laudable, for a country with a population of almost 17 million, the results listed in the government's UPR report underline the complete inadequacy of the scale of its policy response. It notes that '3,133 persons with disabilities in communities have been recognised as the poor and receive social security payments under the state policy scheme' (GoC, 2018: 7, para 25).

(xiii). Social security/ social welfare

Article 26 asserts that 'States Parties shall recognize for every child the right to benefit from social security, including social insurance, and shall take the necessary measures to achieve the full realization of this right in accordance with their national law'. The government's UPR submission is lacking in detail on this issue and offers the generality: 'the RGC [Royal Government of Cambodia] continues to solve and promote people's welfare by introducing specific policies... prioritizing this service to rural and remote areas and to marginalized and vulnerable groups, especially women, children and elders in order to improve people's daily health situation and welfare' (GoC, 2018: 19, para 84). In contrast, 
recent analysis highlights that existing social assistance programmes are highly fragmented, do not operate at sufficient scale, and they are not linked to other social protection programmes. It continues, 'there is a clear case for these programmes to be scaled up... to improve the living conditions of children... [and] there is a clear case for starting social protection interventions earlier, as demonstrated by the high levels of malnutrition among children under five years old' (Organisation for Economic Development and Cooperation - OECD, 2017: 119).

Such concerns are echoed in the UPR discourse. For example, one CSO complained, 'Cambodia's child protection and welfare services remain weak, understaffed and lack funds. Such gaps in welfare services and in poverty levels can lead parents to resort to alternative measures such as unsafe migration, abandonment or placement of children in residential care' (APLE Cambodia \& ECPAT International, 2018: 9). Another called for 'Extending the scope of the National Social Security Recommendation, enlarge the implementation of the pension scheme in support to all Cambodian... children by 2022' (Social Action for Community and Development et al., 2018: 7).

\section{(xiv). Participation in decision-making}

Amongst the remaining issues in the civil society corpus is barriers to the participation of children in decision-making. Article 12 of the CRC asserts that: 'States Parties shall assure to the child... the right to express those views freely in all matters affecting the child'. The importance of participation to the effective implementation of the CRC has been acknowledged by the Association of Southeast Asian Nations (ASEAN) and is reflected in the Hanoi Declaration (ASEAN, 2011). This has seen the creation of a regional body, the ASEAN Children's Forum, to allow children to assert their rights and express their viewpoints. However, the present UPR discourse raises questions about its national counterpart, the Cambodian National Council for Children (CNCC) (RGC, 1995). A key failing noted by CSOs is the absence of descriptive representation: it is 'not composed of children, [yet it is] is a coordinating body that provides comments to the Government on work related to child survival, development, protection, 
promotion of welfare and child participation in implementing action plans relating to the implementation of the Convention on the Rights of the Child' (APLE Cambodia and ECPAT International, 2017: 18). Having examined the key rights violations in the UPR discourse, attention now turns to the way that the discourse is framed.

[Temporary Note - Table 2 - about here]

\section{CSOs' framing of children's rights issues in the UPR data}

Analysis of CSOs' use of language - or framing, in their UPR discourse matters because it informs us of the principles, meanings, messages and emotions they use to persuade diverse audiences including the Cambodian government, the UN and the wider international public - to act to uphold the CRC in policy and practice. As the following analysis reveals, five themes emerge in the CSOs' third cycle UPR discourse. This section is ordered starting with the theme with the highest level of attention or issue salience in the civil society third cycle submissions through to the lowest (see Table 2).

\section{(i). Suffering/victims' experience of child rights violations}

The principal theme is made-up of frames alluding to suffering and victims' experience of child rights violations. It includes exploitation, e.g., 'those who have been sexually abused/exploited experience high levels of trauma, shame and a loss of honour, fears of others finding out and attaching homophobic labels that clearly have a profound impact on their self- esteem' (APLE Cambodia \& ECPAT International, 2017: 11); vulnerability, e.g. 'The CRC Committee expressed its concerns in 2015 that the underlying root causes and contributing factors leading to vulnerability to sexual exploitation are not sufficiently addressed', ECPAT International, 2017: 15) and, exclusion, e.g. 'For children, detention or imprisonment facilitates contacts with older criminals and criminal gangs, leaves them with a criminal record that 
severely hampers future life opportunities, exacerbates social exclusion, and deteriorates their health and social skills' (International Drug Policy Consortium (IDPC) and Asian Network of People who Use Drugs (ANPUD), 2017: 21). This is significant. It suggests strategical awareness on the part of CSOs of the persuasive power of accounts of violations on children themselves. Such framing is designed to humanise the bureaucratic process of the UPR and offer child-centred accounts that appeal to the conscience of officials, parliamentarians and public service providers.

\section{(ii). Improving policy effectiveness}

The second theme is concerned with improving policy effectiveness and comprises a range of frames, including resourcing/budgets/funding. For example, one CSO complained that 'the number of trained social workers at both national and sub-national is inadequate and the ministry has not approved new hiring' (CRC-Cambodia and ADIC, 2017: 5). The need for adequate resourcing is repeated throughout the CSOs' policy recommendations. For example, 'Recommendation: Develop a Child Protection Law in consultation with civil society organizations and development partners, with a sufficient budget allocation for implementation, by 2020' (Child Rights Coalition Cambodia, 2018: 5). The civil society discourse repeatedly highlights how inadequate funding hampers effective policy implementation. For example, one CSO underlined that 'the limited budget, human resources and monitoring and evaluation mechanisms were the main issues. Low budget spending missed geographical areas where there are concentrations of poor children in need. Increasing the budget for implementation of the NAP [National Action Plan for Child Development 2016-2018) and action plans within relevant ministries is imperative' (CRC-Cambodia and ADIC, 2018: 4). Another explained, 'Currently, Cambodia has a system of Commune Committees for Women and Children (CCWCs) to address issues affecting women and children at the local level... Yet, commune budgets favour infrastructure over social services. Each CCWC needs 20 percent of its commune's development budget to more effectively meet the needs of its community' (Cambodian NGO Committee on CEDAW, 2018: 3). 
One of the causes of the underfunding of children's policies is widespread corruption. This affects the allocation of aid, official decision-making and the prosecution of those guilty of children's rights violations. As Feinberg (2009: 289) notes, corruption operates on a massive scale, 'Unofficial fees represent 6 per cent of the country's GNP, as well as about 50 per cent of the government's actual income'. Referring to the judiciary and the police he continues, 'both institutions continue to be politically dominated, rife with cronyism and lacking transparency in decision-making. Correspondingly, breaches in law by the police and the judiciary often continue unchallenged' (p. 290). Such matters are reflected in the civil society UPR discourse. For example, one CSO noted that, 'In 2015, the [United Nations] CRC Committee expressed its deep concerns regarding the low prosecution and conviction rates. Efforts to prosecute and convict [sexual exploitation of children] offenders may be hindered by the widespread practice of out-of-court settlements and high levels of corruption among judicial authorities' (ECPAT International, 2018: 6).

Corruption also affects the other frames in this theme. With regard to monitoring, one CSO captured the wider civil society view by observing that 'the Government's budget to monitor alternative care institutions is still insufficient, leaving children at risk of suffering from unsafe and unhealthy conditions and, being exposed to sexual exploitation' (Cambodian Center for Human Rights Destination Justice, the Cambodian Human Rights and Development Association et al, 2017: 13). In like manner, the discourse on enforcement is typified by the CSO 'Recommendation: Establish and implement Standardized Guideline[s] for Labor Inspections to increase effectiveness of child labor inspection and enforce relevant laws and policies by 2020' (Labor Rights Thematic Group; Solidarity Center Cambodia et al, 2017: 8). The prominence of CSOs' framing in terms of monitoring (with a core trope of better data gathering) and enforcement matters here because it underlines civil society organisations' awareness of the central importance of having an evidence base to counter and criticise government failings, and any attempts by the ruling elite to downplay the seriousness of contemporary rights violations. 


\section{(iii). Principles and norms}

The third theme was principles and norms including the frames: equality, rights, and justice. The framing of equality is illustrated by this CSO, government should 'Promote the rule of law at the national and international levels and ensure equal access to justice for all' (APLE Cambodia \& ECPAT International, 2017: 7). The repeated framing of rights is typified by, 'The legality and practice of corporal punishment of children violates their fundamental human rights' (Global Initiative to End All Corporal Punishment of Children, 2018: 1). Whilst, framing in terms of justice is exemplified by 'Establish one legal mechanism for children to access justice without delay' (Child Rights Coalition Cambodia, 2018: 5). The emphasis on normative values here is again significant. It suggests civil society organisations' use of strategical framing (Pollack, Hafner-Burton, 2000). In other words, the conscious use of language designed to reflect and resonate with the principles and priorities of the UN's rights discourse.

\section{(iv). The need/ motivations for intervention}

The fourth theme was the need for intervention. In other words, the motivations for interventions by the state and/ or other organisations and agencies to promote and uphold children's rights as set out in the CRC. It comprised the frames: protection, prohibition, responding to need and helping. The first of these is typified by one CSO's call to 'Develop a Child Protection Law in consultation with civil society organizations and development partners' (Child Rights Coalition Cambodia, 2018: 15). The second, prohibition, is exemplified by the call to 'enact legislation to explicitly prohibit corporal punishment of children in all settings' (Global Initiative to End All Corporal Punishment of Children, 2018: 14). The CSO discourse also repeatedly frames CRC interventions in terms of responding to need. For example, 'The Cambodian Justice system is evolving but is not yet fully equipped to respond to the need of children who come in contact with the law, whether as victims of SEC [sexual exploitation of children] or as witnesses (Legal Support for Children and Women, 2018: 7). Axiomatically, the remaining frame 'helping' refers to discourse on interventions to uphold the CRC by extending help, support and 
assistance. For example, recommendation to government 'set up a comprehensive data collection system and to analyze data collected as a basis to assess progress achievement in the realization of child rights and to help design policies and programs to implement the Convention' (CRC-Cambodia and ADIC, 2018: 7). This theme's framing resonates with the literature on collective action framing (Benford and Snow, 2000) and informs of the interplay between CSO's views on the motivations to intervene to address violations and the types of intervention required.

\section{(v). Redress}

The last frame was 'redress', including the frames: punishment, for example, the law 'should be amended to eliminate punishment for people suspected of being prostitutes' (Cambodian NGO Committee on CEDAW, ActionAid Cambodia et al, 2018, para 3.6.2) and prosecution, for example 'Efforts to prosecute and convict offenders may be hindered by the widespread practice of out-of-court settlements and high levels of corruption among judicial authorities' (Community Capacity for Development, Kampong Chhnang province, et al 2018: 5). Such framing is again instructive in understanding civil society calls to address children's rights violations. It underlines the centrality of culpability and responsibility for ongoing rights breaches. In turn, such framing aligns with notions of justice (perpetrators must be held accountable), and the importance of this being seen to happen for the deterrent effect it may have. Attention now turns to the final section of this study, the first half of which offers a concluding summary of some of the principal findings. The second discusses the implications of the findings, the current situation in Cambodia and future prospects for CSOs and the promotion of children's rights.

\section{Conclusion and discussion}


Almost three decades on from its ratification of the CRC, Cambodia's lowly international ranking on children's rights reflects serious ongoing violations. This benchmark study has sought to address a lacuna by exploring civil society perspectives on the situation based on the situated knowledge of CSOs in relation to the full breadth of CRC articles. Notwithstanding the government's espousal of co-working with civil society (GoC, 2018: 2), the present analysis has identified a key disjuncture between the situated knowledge of CSOs and government discourse on CRC implementation. It shows that the Government of Cambodia's UPR submission frames matters in instrumental and administrative terms with descriptive, rote-like listing of legal and institutional developments, rather than exhibiting a critical concern with policy efficacy using measurable outcomes. In other words, it is a case of 'legitimation'or 'communicative actions aimed at managing the public's perception that government actions are effective in promoting their desired ends, whether that is in fact true' (Moore, 2001: 712).

In contrast, civil society organisations' submissions to the Third Cycle UPR offer critical perspectives based on their knowledge of the everyday circumstances facing children and young people. They provide powerful accounts of widespread and enduring children's rights violations. Article 34 violations relating to sexual abuse were the first-ranked issue and were shown to be driven by a range of causes including sex tourism, an increase in trafficking and cultural norms meaning that victims seldom disclose abuse. The analysis showed that the government's policy response is wholly unequal to the scale of the problem. For example, nation-wide - out of a population of 16 million, just 45 arrest warrants were issued against suspected traffickers in 2017. A further key problem is the inadequate response to online child exploitation, with no dedicated research capacity, scant police resources and widespread official corruption.

In addition, Article 28 violations reveal access to education to be riven with inequalities, with low overall participation by those in the lower secondary age-band, especially for children in remote areas, those from poor families, and children from ethnic minorities, as well as those with disabilities. CSOs also highlighted how improving the quality of education remains a key challenge. Furthermore, 
examination of Article 19 violations on appropriate legal protection underlines how: children continue to be denied access to legal representation, are not treated in a child-friendly manner in hearings and/or are denied legal aid. These failings are compounded by officials' lack of child-specific knowledge and skills. The present analysis also revealed that child labour continues to be a major, ongoing rights pathology. Almost one-in-five children are economically active. Yet international treaty obligations and the domestic legal code are fraught with contradictions. The government's UPR submission reports troublingly low numbers of child labour cases coming before the courts; with only two cases recorded in 2017. Notably, Article 12 of the CRC enshrines the right to participation of children in decisionmaking. A key failing noted by CSOs is the absence of descriptive representation: the Cambodian National Council for Children is not composed of children, yet it is the coordinating body designed to provide information to government on work related to child protection and welfare.

The implications of the present analysis for the future of CSOs in Cambodia, and their ability to advocate on behalf of children and children's rights are serious. Under increasingly authoritarian conditions, notably with the passing of the 2015 NGO Law, it appears that at best CSOs will have limited, or more likely, no leverage and scope to push the government further on the children's rights violations identified in this study. This is because Cambodia is part of a global trend of governments introducing restrictive legislation on civil society activism that arrests CSOs' ability to hold government to account (Kreienkamp, 2017; . The situation in Cambodia is particularly acute. In November 2020 the UN Special Rapporteur on the situation of human rights defenders (HRD) expressed her 'concerns about tightening restrictions on civil society in Cambodia and called for an immediate end to the systematic detention and criminalisation of HRDs, as well as [the] excessive use of force against them' (OHCHR, 2020: 1). The Special Rapporteur concluded that, 'There seems to be no limit to who the authorities will target, making their actions in recent months appear as a concerted attempt to erode civic space and stifle the work of human rights defenders'. It is also clear that the direction of travel is one of increasing state repression. In March 2021 the government introduced new measures giving it powers to ban or restrict any gathering or demonstration. These were said to be in response to the COVID-19 
pandemic. Yet UN officials condemned the latest crackdown, noting 'we are concerned that the administrative and penal measures, including excessive prison sentences [up to 20 years] and fines [20 million Riels] provided in the law, appear to be disproportionate and unwarranted' (OHCHR, 2021: 1). In the wake of other international examples, such as Bangladesh's Information and Communication Technology Act $(2006, \mathrm{~s} 57)$ that has allowed state monitoring of social media platforms resulting in the detention of civil society activists, further government control and surveillance of Cambodian civil society is likely to follow ( Allied to the increasingly repressive context, a further key failing is the need for an independent human rights monitoring institution that follows Paris Principles (these were adopted by the UN General Assembly in Resolution 48/134 of 1993 and relate to the status and functioning of national institutions for the protection and promotion of human rights). Notwithstanding government's earlier declaration of support for such a body, a 2019 UN report concluded, 'no progress has been made to establish an independent national human rights institution in the State party' (UN Committee on the Elimination of Discrimination against Women, 2019: 3).

The current challenges and areas of negotiation that are at stake in this diminishing civil space span the breadth of children's rights violations identified in this study. Prospects for addressing them do not look good. Written a decade ago, a UN Committee on the Rights of the Child Report (UNCRC, 2011) serves as a reference point underlining the chronic lack of progress to date. It noted 'The Committee urges the State party to take all necessary measures to address... non-discrimination, children with disabilities, adolescent health and juvenile justice' (UNCRC, 2011: 2). Subsequently, in 2015, the Committee demanded 'that the State party [must] intensify its efforts to develop and implement a comprehensive, coordinated and effective system of data collection, analysis, monitoring and impact assessment on all areas... including on child prostitution, child pornography and child sex tourism' (UNCRC, 2015: 2). The present study confirms the lack of progress on all these issues.

As Cole (2015: 405) asserts, gaps between human rights principles and practices are often due to ineffective enforcement, and limited state capacity to effect change owing to political and 
bureaucratic failings. This resonates with the present study and the disjuncture between the situated knowledge of CSOs and government discourse on CRC implementation. Civil society UPR submissions repeatedly emphasise the need for greater resources, coordination, monitoring, and data. A further core element in the malaise is the government's failure to fully implement the recommendations of earlier UPR cycles. This stems from a key failing in the UPR process; namely that UN treaties like the CRC are not justiciable unless they are incorporated into the domestic legal code. As the present analysis reveals, this means that government can pay lip-service to treaty implementation but violate with impunity.

In summary, the variables involved with future change or atrophy that are critical to children's rights include: effective monitoring, data and legal enforceability of CRC obligations; civil society independence and criticality; greater public awareness of the governing regime's CRC obligations; adequate resourcing of CSOs; and international monitoring and support. At the beginning of this article, it was suggested that future progress depends on strengthened civil society mobilisation. However, as the foregoing analysis explains, this is highly unlikely owing to increasing repression by Cambodia's autocratic government. Without fundamental revisions to the powers of the UN and the justiciability of the CRC and/or regime change, the prospects are bleak. Over coming years children in Cambodia are likely to continue to suffer widespread rights violations.

\section{Acknowledgements}

The author is grateful to the editors and two anonymous reviewers for helpful and constructive comments on an earlier draft of this paper. Research funding from the Research Council under Award No is also gratefully acknowledged. 


\section{APPENDIX 1}

ADF International Chemin du Petit-Saconnex 281209 Geneva, Switzerland

Global Initiative to End All Corporal Punishment of Children

International Trade Union Confederation

International Drug Policy Consortium (IDPC) and Asian Network of People who Use Drugs (ANPUD)

Minority Rights Organisation (MIRO), Khmer Kampuchea Krom for Human Rights and Development Association (KKKHRDA), Institute on Statelessness and Inclusion (ISI), Statelessness Network Asia Pacific (SNAP) and Minority Rights Group International (MRG)

Joint Submission: Khmer Kampuchea Krom for Human Rights and Development Association (KKKHRDA), Minority Rights Organization (MIRO), Alliance for Conflict Transformation (ACT), Cambodian Center for Human Rights (CCHR), Khmer Kampuchea Krom Community (KKKC), Union of the Khmer Kampuchea Krom Buddhist Monk Students (UKKBS), Friendship of Khmer Kampuchea Krom Association (FKKKA), Khmer Kampuchea Krom Cultural Center (KKKCC), Khmer Fund for the Poor (KFP).

Joint Submission: Labor Rights Thematic Group; Solidarity Center Cambodia (ACILS); Independent Democracy of Informal Economy Association (IDEA); Cambodian Youth Network (CYN); Cambodian Food and Service Workers Federation (CFSWF); The Cambodian Confederation Unions (CCU); Cambodian Labor Confederation (CLC); Center for Alliance of Labor and Human Rights (CENTRAL); Coalition of Cambodian Farmer Community Association (CCFC); Legal Support for Children and Women (LSCW).

Joint Submission: The Cambodian NGO Committee on CEDAW (NGO-CEDAW); ActionAid Cambodia; Cam-ASEAN Youth's Future; Cambodian Center for Human Rights (CCHR); DanChurchAid, Cambodia (DCA); Gender and Development for Cambodia (GADC); Gender and Development Network (GADNet); Khmer Youth and Social Development (KYSD); Legal Support for Children and Women (LSCW); Rainbow Community Kampuchea (RoCK); SILAKA; Solidarity Center, Cambodia (SC); Women's Network for Unity (WNU)

Joint Submission: by the Social Action for Community and Development ("SADC"), Women's Network for Unity ("WNU"), Rainbow Community Kampuchea ("RoCK"), and Health Action Coordination Committee ("HACC").

Situation of Indigenous Peoples in Cambodia

Joint Submission: to the Universal Periodic Review of Cambodia by ARTICLE 19 and PEN America Joint Submission: CRC-Cambodia and ADIC

Joint Submission: Community Capacity for Development (CCD) (Kampong Chhnang province); Children and Women Development Center in Cambodia (CWDCC); Cambodian Youth Network Association (CYN); Urban Poor Women Development (UPWD); Cambodian Coalition of Farmer Communities Association (CCFC); Green Vision Organization (GVO); Cambodian Grassroots Crosssector Network (CGCN); WVI-C/Disaster Risk Management and Land Tenure Security Project (DRM/LTS); Building Community Voices (BCV); CCD (Cambodia Community Development (Kratie province); Sahmakum Teang Tnaut (STT); Partnership for development in Cambodia (Padek); 
Community Translation Organization (CTO); NGO Forum on Cambodia; Ponlok Khmer (PKH); Star Kampuchea (SK); and Cambodian Volunteers for Society (CVS)

Joint Submission: the Cambodian Center for Human Rights ("CCHR"), Destination Justice ("DJ") and The Cambodian Human Rights and Development Association ("ADHOC"), and endorsed by Advocacy and Policy Institute ("API"), Transparency International Cambodia ("TIC"), and International Freedom of Expression Exchange ("IFEX").

APLE Cambodia \& ECPAT International

Cambodian Disabled People's Organisation (CDPO) was established in 1994 as a movement of Cambodian persons with disabilities

Joint Submission: Independent Democracy of Informal Economy Association 


\section{References}

Ahmed, S., Rawal, L., Chowdhury, S. (2016) Cross-country analysis of strategies for achieving progress towards global goals for women's and children's health. Bull World Health Organ; 94(1): 351-61. doi:10.2471/BLT.15.168450

Arnold D, and Hess, M. (2017) Governmentalizing Gramsci: Topologies of power and passive revolution in Cambodia's garment production network. Environment and planning. A, 49 (10): 21832202.

ASEAN (2011) The Declaration on the Elimination of Violence Against Women and Elimination of Violence against Children in ASEAN, Hanoi: ASEAN.

https://www.ohchr.org/Documents/Issues/Women/WG/ASEANdeclarationVaW violenceagainstchildr en.pdf

Benford R and Snow D (2000) Framing processes and social movements: An overview and assessment. Review of Sociology, 26: 611-39.

Bertelsmann Stiftung Transformation Index (2021) Cambodia Country Report https://www.btiproject.org/en/reports/country-report-KHM-2020.html [Last accessed 03.03.21]

Biber D, Connor U and Upton T (2007) Discourse on the move using corpus analysis to describe discourse structure. Amsterdam; Philadelphia: John Benjamins Pub. Co. 
Bureau of International Labor Affairs (2019) 2018 Findings on the Worst Forms of Child Labor: Cambodia. Washington: US Department of Labor.

https://www.dol.gov/sites/dolgov/files/ILAB/child labor reports/tda2018/Cambodia.pdf [Last accessed 28.02.21]

Chiu C (2007) Workplace practices in Hong Kong-invested garment factories in Cambodia. Journal of contemporary Asia, 37(4): 431-448.

Chon K, Bauer T and Mckercher B (2003) Sex and Tourism: Journeys of Romance, Love, and Lust, NY, London and Oxford: Haworth Press.

Cole W (2015) Mind the Gap: State Capacity and the Implementation of Human Rights Treaties. International Organization, 69(2): 405-441.

Curley M (2018) Governing Civil Society in Cambodia: Implications of the NGO Law for the "Rule of Law". Asian Studies Review, 42(2): 247-267, DOI:10.1080/10357823.2018.1457624

Curley M, Dressel B and McCarthy S (2018) Competing Visions of the Rule of Law in Southeast Asia: Power, Rhetoric and Governance. Asian Studies Review, 42(2): 192-209. 
Dalal K, Parvin Nuri R, Shinn Lee M, Kuang Lin, C, Gifford M, Ussatayeva G. and Biswas A (2018) Attitudes of women in Cambodia towards child physical abuse. F1000 Research, 7:1866.

Druckman J (2001) The implications of framing effects for citizen competence. Political Behavior, 23(3): 225-256.

Economist Intelligence Unit (2021) Democracy Index 2020: In sickness and in health? London: Economist Intelligence Unit.

ECPAT International (2018) Cambodia, ECPAT Country Overview: A report on the scale, scope and context of the sexual exploitation of children, Bangkok: ECPAT https://www.ecpat.org/wpcontent/uploads/2018/04/ECPAT-Country-Overview-Cambodia.pdf [Last accessed 06.08.21]

Feinberg G (2009) The epidemic of petit corruption in contemporary Cambodia: Causes, consequences and solutions. Crime Prevention and Community Safety, 11, 277-296.

Franceschini I (2020) At the Roots of Labour Activism: Chinese and Cambodian Garment Workers in Comparative Perspective. Journal of contemporary Asia, 50(1): 144-167.

Franciscans International (FI) and Marist Foundation for International Solidarity (FMSI) (2009) Joint Submission to the Universal Periodic Review (UPR) of Cambodia, 6th Session, Geneva: FI and FMSI. 
Gartrell A (2010) 'A frog in a well': the exclusion of disabled people from work in Cambodia. Disability \& Society, 25(3): 289-301.

Glenn M and Thomas N (1992) 'Don't grind an egg against a stone' - children's rights and violence in Cambodian history and culture. Child Abuse Review, 16(6): 383-400.

Global Initiative to End All Corporal Punishment of Children (2014) Submission to the Universal Periodic Review (UPR) of Cambodia, 6th Session, Geneva: Global Initiative.

Goffman E (1974) Frame analysis. Cambridge: Harvard University Press.

Government of Cambodia (2018) National report submitted in accordance with paragraph 5 of the annex to Human Rights Council resolution 16/21: Cambodia. NY: Human Rights Council, A/HRC/WG.6/32/KHM/1

Hall J (2000) Human rights and the garment industry in contemporary Cambodia. Stanford journal of international law, 36(1): 119.

Haworth A (2014) "Virginity for sale: inside Cambodia's shocking trade", The Guardian, accessed 14 August 2021, https:// www.theguardian.com/society/2014/jul/06/virginity-for-sale-cambodia-sex$\underline{\text { trade }}$ 
Heine B and Narrog H. (2015) The Oxford handbook of linguistic analysis (2nd ed.) Oxford: Oxford University Press.

Hoefinger H (2013) Sex, love and money in Cambodia professional girlfriends and transactional relationships. Oxfordshire, England; New York: Routledge.

Hughes C (2009) Dependent Communities: Aid and Politics in Cambodia and East Timor, Ithaca and New York: Cornell University Press.

Human Rights Council (2009) Working Group on the Universal Periodic Review, Sixth session Geneva, 30 November-11 December 2009, National Report Submitted in Accordance with Paragraph 15 (A), of the Annex to Human Rights Council Resolution 5/1* Cambodia, A/HRC/WG.6/6/KHM/1, Geneva: HRC.

Human Rights Council (2014a) Working Group on the Universal Periodic Review, Eighteenth session 27 January - 7 February 2014, National Report Submitted in Accordance with Paragraph 15 (A), of the Annex to Human Rights Council Resolution 5/1* Cambodia, A/HRC/WG.6/18/KHM/1, Geneva: HRC.

Human Rights Council (2014b) Cambodia, Second Review, Session 18, Review in the Working Group: 28 January 2014, Adoption in the Plenary: 26 June 2014, Cambodia's responses to recommendations (as of 14.08.2014), Geneva: HRC. 
Interagency Working Group (2016) Terminology Guidelines for the Protection of Children from Sexual Exploitation and Sexual Abuse Adopted by the Interagency Working Group in Luxembourg, 28 January 2016, Bangkok, Office of the High Commissioner for Human Rights

https://www.ohchr.org/Documents/Issues/Children/SR/TerminologyGuidelines en.pdf [Last accessed 27.02.21]

International Labor Organisation and International Trade Union Confederation (2018) Kram Dated March 13, 1997 on the Labor Law, Brussels: International Trade Union Confederation

https://www.ilo.org/global/standards/applying-and-promoting-international-labourstandards/committee-of-experts-on-the-application-of-conventions-and-recommendations/lang-en/index.htm [Last Accessed 25.07.21]

Jegannathan B, Kullgren J. and Deva P (2015) Mental health services in Cambodia, challenges and opportunities in a post-conflict setting. Asian Journal of Psychiatry 13: 75-80.

Joamets K and Ngouv M (2019) A Child's Right to Be Heard and Be Represented in the Criminal Procedure: A Comparative Analysis of Estonian and Cambodian Law to CRC. Baltic journal of European Studies, 9(4): 127-149.

Karpati J, de Neubourg C, Laillou A and Poirot E (2020) Improving children's nutritional status in Cambodia: Multidimensional poverty and early integrated interventions. Maternal \& child Nutrition, 16(S2): e12731. 
Kelsall T, Khieng S, Chantha C. and Tek Muy T. (2019) 'The Political Economy of Primary Education Reform in Cambodia' Chapter 7 (pp. 86-94) in Sam Hickey and Naomi Hossain (eds) The Politics of Education in Developing Countries: From Schooling to Learning, Oxford: Oxford University Press.

Khmer Kampuchea Krom for Human Rights and Development Association (2014) Submission to the Universal Periodic Review (UPR) of Cambodia, 6th Session, Geneva: KKKHRDA.

KidsRights Foundation and Erasmus University Rotterdam (2021) A Ranking for all UN member states that have ratified the UN Convention on the Rights of the Child, KidsRights Foundation and Erasmus University. https://kidsrights.org/research/kidsrights-index/ [Last Accessed 22.07.21]

Kingdom of Cambodia (2014) National Action Plan on Early Childhood Care and Development 20142018, Phnom Penh: National Committee of Early Childhood Care and Development.

Kingdom of Cambodia (2017a) Positive Parenting Strategy 2017-2021. Phnom Penh: Royal Government of Cambodia.

Kingdom of Cambodia (2017b) Action Plan to Prevent and Respond to Violence Against Children 2017-2021. Phnom Penh: Royal Government of Cambodia.

https://www.aidsdatahub.org/sites/default/files/resource/cambodia-action-plan-prevent-andrespond-violence-against-children-2017.pdf 
Klijn E and Skelcher C (2007) Democracy and governance networks: Compatible or not? Public Administration, 85(3): 587-608.

Kreienkamp J (2017) Responding to the Global Crack-Down on Civil Society, Policy Briefing, London: University College London: Global Governance Institute. https://www.ucl.ac.uk/globalgovernance/sites/global-governance/files/policy-brief-civil-society.pdf

Locard H (2004) Pol Pot's Little Red Book: The Sayings of Angkar. Silkworm Books: Chiang Mai, Thailand.

Loughlin N (2021) Chinese linkage, leverage, and Cambodia's transition to hegemonic authoritarianism, Democratization, 28(4): 840-857.

Mak M and Nordtveit B H (2011) "Reasonable Accommodations" or Education for All? The Case of Children Living with Disabilities in Cambodia. Journal of Disability Policy Studies, 22(1): 55-64.

McCarthy S and Un K (2017) The evolution of rule of law in Cambodia. Democratization, 24(1): 100118.

Moore L (2001) Legitimation issues in the state-nonprofit relationship. Nonprofit and Voluntary Sector Quarterly, 30(1): 707-719. 
Ministry of Education, Youth and Sport (2018) The Education, Youth and Sport Performance in the Academic Year 2017-2018, and Goals For The Academic Year 2018-2019. Phnom Penh: Ministry Of Education, Youth and Sport.

http://planipolis.iiep.unesco.org/sites/planipolis/files/ressources/cambodia education congress rep ort 2018-2019 eng.pdf [Last accessed 25.02.21]

Ministry of Social Affairs, Veterans and Youth Rehabilitation (2017) Mapping of Residential Care Facilities in the capital and 24 provinces of the Kingdom Of Cambodia, Phnom Penh: Ministry of Social Affairs, Veterans and Youth Rehabilitation, https://bettercarenetwork.org/sites/default/files/Mapping\%20of\%20Residential\%20Care\%20in\%20Ca mbodia.pdf [Last accessed 25.07.21]

National Assembly of Cambodia (1997) Labor Code adopted by the National Assembly on January 10, 1997 during the 7th Session of the First Legislature. Phnom Penh: National Assembly of Cambodia. https://www.ilo.org/dyn/travail/docs/701/Labour\%20Law.pdf

National Assembly of Cambodia (2004) The Civil Code of Cambodia. Phnom Penh: National Assembly of Cambodia. https://www.trc.gov.kh/wp-content/uploads/2015/05/civil-code-en.pdf

National Assembly of Cambodia (2008) The Civil Code of Cambodia. Phnom Penh: National Assembly of Cambodia, https://www.trc.gov.kh/wp-content/uploads/2015/05/civil-code-en.pdf [Last accessed 14.08.21] 
Neuendorf K (2016) The Content Analysis Guidebook. Thousand Oaks, Ca. SAGE.

NGO Coalition on the Rights of the Child (2019) Joint Submission to the Universal Periodic Review (UPR) of Cambodia, 6th Session. Geneva: NGOCRC.

Office of the High Commissioner for Human Rights (OHCHR) (2011) The Universal Periodic Review. Geneva: OHCHR.

Office of the High Commissioner for Human Rights (1985) United Nations Standard Minimum Rules for the Administration of Juvenile Justice ("The Beijing Rules"), Adopted by General Assembly resolution 40/33 of 29 November 1985. NY: OHCHR.

Office of the High Commissioner for Human Rights (2019) Universal Periodic Review (Third Cycle): Information and guidelines for relevant stakeholders' written submissions. NY: OHCHR https://www.ohchr.org/en/hrbodies/upr/pages/ngosnhris.aspx

Office of the High Commissioner on Human Rights (2020) Cambodia: UN experts alarmed by civil society crackdown, attacks on defenders. Geneva: OHCHR https://www.ohchr.org/en/NewsEvents/Pages/DisplayNews.aspx?NewsID=26505\&Lang|D=E 
Office of the High Commissioner on Human Rights (2021) UN experts urge Cambodia to review approach to COVID-19. Geneva: OHCHR

https://www.ohchr.org/EN/NewsEvents/Pages/DisplayNews.aspx?NewsID=26985\&LangID=E

Ong K, Cherng I, Yi S, Tuot S, Chhoun P, Shibanuma A, Yasuoka J and Jimba M (2015) What are the factors associated with depressive symptoms among orphans and vulnerable children in Cambodia? BMC Psychiatry, 15(1): 178-178.

Ojendal, J and Ou S (2015) The "local" turn saving liberal peacebuilding? Unpacking virtual peace in Cambodia. Third World Quarterly, 36(5): 929-949.

OECD (2017) "Systematising social protection in Cambodia", Chapter 4 (pp. 113-133) in Social Protection System Review of Cambodia, Paris: OECD Publishing, DOI: https://doi.org/10.1787/9789264282285-9-en

Page K, SteinE., Carrico A, Evans J, Sokunny M, Nil E Ngak S, Sophal C, McCulloch C and Maher L (2016) Protocol of a cluster randomised stepped-wedge trial of behavioural interventions targeting amphetamine-type stimulant use and sexual risk among female entertainment and sex workers in Cambodia, BMJ Open, 6(5): e010854-e010854

People Health Development Association (2009) Submission to the Universal Periodic Review (UPR) of Cambodia. 6th Session, Geneva: UN. 
Peou S (2019) Cambodia's hegemonic-party system: How and why the CPP became dominant. Asian Journal of Comparative Politics. 4(1): 42-60.

Pollack Mand Hafner-Burton E (2000) Mainstreaming Gender in the European Union. Harvard Jean Monnet Working Paper 2, Harvard Law School, Cambridge, MA

https://www.jeanmonnetprogram.org/archive/papers/00/000201.html [Last accessed 06.03.2021]

Popovic V and Melim-McLeod C and UNDP (2009) Access to Justice in Cambodia Project Assessment Report, NY: UNDP

https://info.undp.org/docs/pdc/Documents/KHM/00042256 Final\%20Evaluation\%20Report\%202009 .pdf [Last accessed 27.07.21]

Royal Government of Cambodia (1995) Anu-Kret/ Sub-Decree on the Establishment of the Cambodian National Council for Children. Phnom Penh: RGC.

Royal Government of Cambodia and UNICEF (2016) The Royal Government of Cambodia - UNICEF Country Programme Action Plan 2016 - 2018. Phnom Penh: RGC/ UNICEF.

http://files.unicef.org/transparency/documents/Cambodia CPAP 2016-2018.pdf [Last accessed 27.07.21]

Royal Government of Cambodia (2016a) Master Plan for Child Friendly School 2015-2018. Phnom Penh: RGC. 
Royal Government of Cambodia (2016b) Policy on Child Protection in School 2016. Phnom Penh: RGC.

Royal Government of Cambodia (2014) Education Strategic Plan 2014-2018. Phnom Penh: RGC.

Shea A, Nakayama M and Heymann J (2010) Improving Labour Standards in Clothing Factories: Lessons from Stakeholder Views and Monitoring Results in Cambodia. Global social policy, 10(1): 85-110.

Stark L, Rubenstein B, Pak K and Kosal S (2017) National estimation of children in residential care institutions in Cambodia: a modelling study, BMJ Open, 7(1): e013888-e013888

Tyner J (2018) Gender and sexual violence, forced marriages, and primitive accumulation during the Cambodian genocide, 1975-1979, Gender, Place and Culture: A Journal of Feminist Geography, 25(9): $1305-1321$. 
Un K (2019) Cambodia: Return to Authoritarianism, Cambridge: Cambridge University Press.

United Nations (1948) Universal Declaration of Human Rights. NY: UN.

https://www.ohchr.org/EN/UDHR/Pages/UDHRIndex.aspx

United Nations (1966) International Covenant on Civil and Political Rights. NY: UN.

https://www.ohchr.org/en/professionalinterest/pages/ccpr.aspx

United Nations (2010) Responses to Recommendations: Cambodia, Review in the Working Group: 1 December 2009, Adoption in the Plenary: 17 March 2010, NY: UN.

United Nations Country Team (2009) Country Team Report: Cambodia, Geneva: United Nations.

UNICEF (2017) The State of the World's Children 2017 Statistical Tables,

https://data.unicef.org/resources/state-worlds-children-2017-statistical-tables/ [Last accessed 26.02.21]

UNICEF (2019a) UNICEF in Cambodia Country Programme 2019-2023, Phnom Penh: UNICEF.

https://www.unicef.org/cambodia/media/2361/file/CountryProgramme OVERVIEW 25x25 2019 Fin al.pdf\%20.pdf [Last accessed 26.02.21] 
UNICEF (2019) Cambodia celebrates 30 years of protecting children's rights with \#everyright4everychild campaign, 30.11.19 https://www.unicef.org/cambodia/press-releases/cambodia-celebrates-30-yearsprotecting-childrens-rights-

everyright4everychild\#: :text=Cambodia\%20ratified\%20CRC\%20in\%200ctober,school\%20\%E2\%80\%9 3\%20more\%20than\%20ever\%20before. [Last accessed 26.02.21]

United Nations Action for Cooperation against Trafficking in Persons (2016) Human Trafficking and Vulnerabilities in Asia: A Study of Forced Marriage between Cambodia and China, Bangkok: UN-ACT. http://un-act.org/wp-content/uploads/2016/08/Final UN-ACT Forced Marriage Report.pdf [Last accessed 28.07.21]

UNICEF (2019) Cambodia celebrates 30 years of protecting children's rights with \#everyright4everychild campaign, 30.11.2019 Phnom Penh: UNICEF.

https://www.unicef.org/cambodia/press-releases/cambodia-celebrates-30-years-protectingchildrens-rights-everyright4everychild [Last accessed 03.07.2021]

UNICEF, Australia Aid, UN Women, UN FPA (2020) Ending Violence Against Women and Children in Cambodia, Bangkok: UNICEF East Asia and the Pacific Regional Office. 
United Nations Committee on the Rights of the Child (2011) Fifty-seventh session 30 May - 17 June 2011, Consideration of reports submitted by States parties under article 44 of the Convention Concluding observations: Cambodia, Geneva: OHCHR https://tbinternet.ohchr.org/layouts/15/treatybodyexternal/Download.aspx?symbolno=CRC/C/KHM $\angle C O / 2 \&$ Lang=En

United Nations Committee on the Rights of the Child (2015) Concluding observations on the report submitted by Cambodia under article 12, paragraph 1, of the Optional Protocol to the Convention on the Rights of the Child on the sale of children, child prostitution and child pornography, CRC/C/OPSC/KHM/CO/1, Geneva: UNCRC https://tbinternet.ohchr.org/ layouts/15/treatybodyexternal/Download.aspx?symbolno=CRC/C/OPSC /KHM/CO/1\&Lang=En

United Nations Committee on the Elimination of Discrimination against Women (2019) Concluding observations on the sixth periodic report of Cambodia, CEDAW/C/KHM/CO/6, Geneva: United Nations. https://tbinternet.ohchr.org/ layouts/15/treatybodyexternal/Download.aspx?symbolno=CEDAW/C/K $\underline{\mathrm{HM} / \mathrm{CO} / 6 \& \text { Lang=En }}$

United Nations Country Team (UNCT), Cambodia (2018) Joint UNCT Cambodia Report in the context of Cambodia's third UPR cycle, Phnom Penh: UNCT.

Van Dijk Teun A (2001). Chapter 18: Critical discourse analysis. In Deborah Schiffrin, Deborah Tannen and Heidi Hamilton (Eds), Handbook of Discourse Analysis (pp. 353-371). Oxford: Blackwell. 
Cambodia,

https://www.worldbank.org/en/country/cambodia/overview [Last accessed 25.02.21]. 